Mirjana Kovačić

E-mail: mirjana051@gmail.com

Nikolina Eva Pahljina

E-mail: n.e.pahljina@gmail.com

Astrid Zekić

E-mail: astrid.zekic@gmail.com

University of Rijeka, Faculty of Maritime Studies, Studentska 2, 51000 Rijeka, Croatia

\title{
A Comparative Analysis of Accommodation Capacities of Nautical Tourism Ports in Croatia and in the Primorje-Gorski Kotar County
}

\begin{abstract}
Croatia is one of the major Mediterranean destinations for nautical tourism owing to its countless attractions, indented coastline, numerous islands, climatic and other advantages. An important factor for achieving a full development potential is the availability of infra- and supra-structure, which is reflected through investments in new marinas, anchorages and other facilities.

The article analyses accommodation capacities of ports for nautical tourism in Croatia. The authors give an overview of the current situation with an emphasis on the County of Primorje-Gorski Kotar. The purpose of this article is to analyse the growing need for accommodation capacities in nautical tourism ports and to point to the importance of building new marinas and berths, especially for boats long between 12 and 15 meters.
\end{abstract}

Key words: nautical tourism, ports, accommodation capacities, Croatia, the Primorje-Gorski Kotar County

\section{Introduction}

Croatia's seashore and its island archipelago with more than a thousand islands make it recognizable on the tourism market. This exceptional natural resource base contributes to the development of nautical tourism, which is expected to achieve its full development potential in the upcoming time.

Nautical tourism is a special form of tourism that includes vacation and recreation and which, owing to its socio-economic impacts, represents an increasingly important developmental touristic and economic potential. The goals of the development of 
nautical tourism arise from the vision that Croatia should become one of the most desirable destinations for nautical tourists in the Mediterranean. Following the trends in the Mediterranean and in Croatia, it has been noted that Croatia has been continually short in berths, especially the ones for larger boats.

The County of Primorje-Gorski Kotar is one of the seven coastal counties and therefore has the potential for further development of nautical tourism. However, the existing condition of nautical tourism ports is not satisfying. Although there have been plans of locations for new ports in place, the development of marinas has been very slow.

\section{Theoretical background}

Nautical tourism is one of the fastest growing segments of maritime activities that are beginning to massively develop in the world alongside with all other forms of maritime tourism. While other factors of tourist offer (political, organizational, receptive) can change and improve over time, the degree of attractiveness of natural resources is a lasting and unchangeable value. Indented coast and attractive islands are prerequisites for the development of nautical tourism.

Owing to its geo-communication position, one of the most indented coastlines in the world, a pleasant climate and favourable winds, Croatia is today one of the highly desirable nautical destinations in the world [3]. Nautical tourism in Croatia has developed thanks to its pristine coastline with numerous bays, coves and islands, its clean and pleasantly warm sea, and the great variety and contrasts in the landscape due to the suitable Mediterranean climate [10]. Nautical tourism has a very high multiplier effect allowing it to become one of the most competitive products of Croatia in the world [4].

The composition, richness and attractiveness of its natural resources place Croatia ahead of many European tourist countries [1]. When compared with competing countries such as Spain, France, Italy, Greece and Turkey, Croatia is constantly rated better than its competition with respect to personal safety, the attractiveness and preserved state of nature and the environment, the climate and purity of the sea and coastal places, as well as to some social elements, like hospitality and the image it has as a country. Croatia's comparative advantages are its natural beauty, landscape picturesqueness and ecological preservation - all important features for the development and future of nautical tourism - but this does not suffice. The development of nautical tourism is conditioned not only by the attractiveness of natural features, which do abound in our country, but also by adequate marinas, moorings, berths and other accompanying facilities. In addition to physical advantages of the Croatian coast, it is interesting and important to consider how berthing capacities are dispersed along the Croatian coast. 


\section{The status of accommodation capacity in nautical tourism ports in Croatia}

In contrast to world trends, the development of nautical tourism in Croatia had had a slower trend until the early 1980's. An intensified development of nautical tourism started with the foundation of the Adriatic Croatia International Club for the activities of marinas (ACI d.d.), which initiated the construction of 16 marinas (Umag, Rovinj, Pula, Pomer, Rab, Supetarska Draga, Žut, Piškera, Vodice, Skradin, Jezera, Trogir, Split, Milna, Vrboska and Palmižana). By the end of the 1980's, marinas were built in Korčula and Opatija, and in the early 1990's also in Dubrovnik, Šimuni and Cres. The last marina built in the series of ACI marinas was the one of Slano near Dubrovnik, which started its activity in 2016. Alongside the development of ACI marinas, other marinas along the Croatian coast were also built. The number of nautical tourism ports in Croatia in the period from 2006 to 2016 is shown in Table 1.

Table 1 - Nautical tourism ports in the Republic of Croatia

\begin{tabular}{|c|c|c|c|c|c|c|c|}
\hline 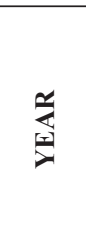 & 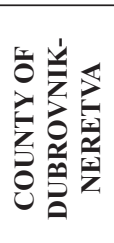 & 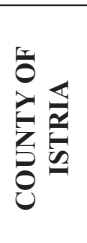 & 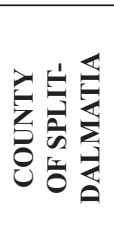 & 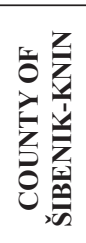 & 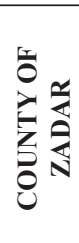 & 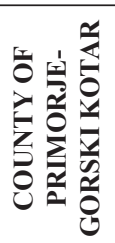 & 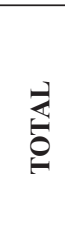 \\
\hline 2006 & 6 & 14 & 11 & 11 & 24 & 29 & 95 \\
\hline 2007 & 5 & 14 & 11 & 11 & 23 & 30 & 94 \\
\hline 2008 & 5 & 14 & 11 & 11 & 24 & 32 & 97 \\
\hline 2009 & 4 & 14 & 13 & 11 & 24 & 32 & 98 \\
\hline 2010 & 5 & 15 & 13 & 11 & 24 & 30 & 98 \\
\hline 2011 & 6 & 15 & 13 & 13 & 21 & 30 & 98 \\
\hline 2012 & 6 & 15 & 16 & 13 & 19 & 29 & 98 \\
\hline 2013 & 6 & 14 & 17 & 14 & 23 & 32 & 106 \\
\hline 2014 & 6 & 14 & 21 & 15 & 26 & 30 & 112 \\
\hline 2015 & 7 & 14 & 20 & 17 & 36 & 27 & 121 \\
\hline 2016 & 8 & 13 & 27 & 21 & 44 & 26 & 139 \\
\hline
\end{tabular}

Source: Authors according to [11] 
The total number of nautical tourism ports within the territory of Croatia in the observed ten-year period was constantly increasing; indeed, it increased by $46 \%$, or by 44 nautical ports, having reached the number of 58 marinas in 2016.

However, the ports for nautical tourism along the Croatian coast have not been evenly distributed. The Mid-Adriatic area has doubled the number of nautical tourism ports, particularly the County of Zadar, which, with its 20 newly built ports, has taken the lead in the number of nautical tourism ports along the entire Croatian coastline. In contrast, the southern part of Croatia has the least number of nautical tourism ports, while their number in the Counties of Primorje-Gorski Kotar and Istria varied over the ten-year period. Contrary to other counties, the County of Lika-Senj is still recording no development in the direction of nautical tourism.

The goals set for the development of nautical tourism arise from the vision that Croatia should become one of the most desirable nautical destinations in the Mediterranean, a position it deserves owing to its indented coastline, preserved and civilized living on the coastline and islands, the quality of nautical infrastructure and safety of stay and thematic itineraries [9]. The Strategy for the development of nautical tourism of the Republic of Croatia for the period 2009-2019 proposes the construction of 5000 new berths in existing nautical ports, 5000 berths in new locations and 5000 lots for onshore accommodation of boats which would be evenly distributed along the Croatian coastline and islands. In particular, the Strategy [8] emphasizes that in the planning of the construction of berths, it is necessary to take into account the rising trend recorded in respect of arrivals of large yachts that the existing infrastructure is unable to accommodate. It is obvious that the problem of arrangement and distribution of nautical tourism ports will be one of the key strategic objectives of the macrodevelopment policy in the future [6].

\section{Ports in the County of Primorje-Gorski Kotar}

Its long maritime history and tradition, favourable geographic position, exceptional natural and cultural sites situated along the $1065 \mathrm{~km}$ of coastline, covering an area of $636630 \mathrm{~m}^{2}$, classify the County of Primorje-Gorski Kotar as one of Croatia's most developed maritime counties. Although nautical tourism gives a significant contribution to the tourism industry of the County, this contribution is far from satisfactory.

Here follows an overview of the current position of nautical tourism along with a research of possibilities for the development of nautical tourism in the County of Primorje-Gorski Kotar. 


\subsection{Existing ports for nautical tourism in the County of Primorje-Gorski Kotar}

The County of Primorje-Gorski Kotar counts 26 nautical tourism ports, which makes about $18.7 \%$ of all nautical tourism ports in Croatia. Out of these 26 ports, eight are anchorages, three are moorings, five are land marinas, one is a $1^{\text {st }}$ category marina, two are $2^{\text {nd }}$ category marinas, three are $3^{\text {rd }}$ category marinas and four are marinas categorized and marked by anchors. The marinas have been equally deployed within the coastal area of the County of Primorje-Gorski Kotar with a total available capacity of 2891 berths, while the boat accommodation on land counts 1488 dry berths. It is important to emphasize that Marina Punat, ACI-Marina Opatija and ACI-Marina Cres are holders of the Blue Flag 2017. The most significant destinations for nautical tourism in the County of Primorje-Gorski Kotar are Rab, Mali Lošinj, Cres, Punat and Opatija.

In the observed ten-year period, the number of nautical tourism ports in Croatia has been continuously increasing, but in the County of Primorje-Gorski Kotar their number has varied between 26 and 32. The same trend has been observed in the number of berths. A comparison of the respective number of berths in Croatia and in the County of Primorje-Gorski Kotar in the period 2006 - 2016 is shown in the graph in Figure 1.

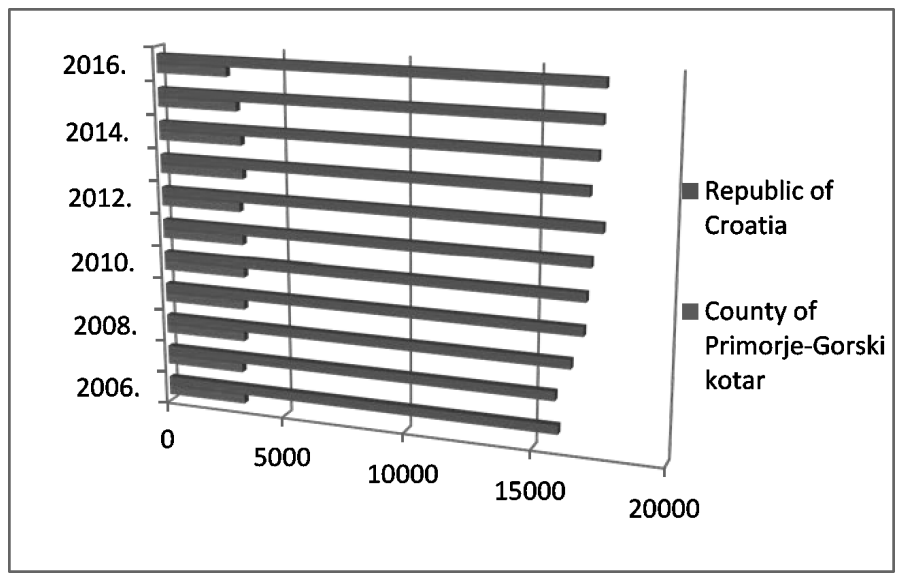

Figure 1 - Number of nautical berths in the Republic of Croatia and County of Primorje-Gorski kotar, 2006 - 2016, according to [11] 
It can be seen that while the total number of berths in Croatia was increasing, their number in the County of Primorje-Gorski Kotar had a different trend. Namely, although their number did increase at two points in the observed period, it dropped on the whole from 3281 in 2006 to 2891 in 2016 and consequently their share in Croatia as a whole also dropped from the initial figure of $20.5 \%$ in 2006 to $16.6 \%$ in 2016 . Apart from berths within the ports of nautical tourism, the County of Primorje-Gorski Kotar has around 30,000 berths in special purpose ports. The majority of these berths have been used by the local population, while a small percentage of them has been providing services to nautical tourists mostly in transit.

In 2016, the ports of nautical tourism in the County of Primorje-Gorski Kotar achieved a total income of HRK 101,482,000 which represents about $13.2 \%$ of the total income in Croatia as a whole. The analysis of incomes in 2015 and 2016 is shown in the graph in Figure 2.

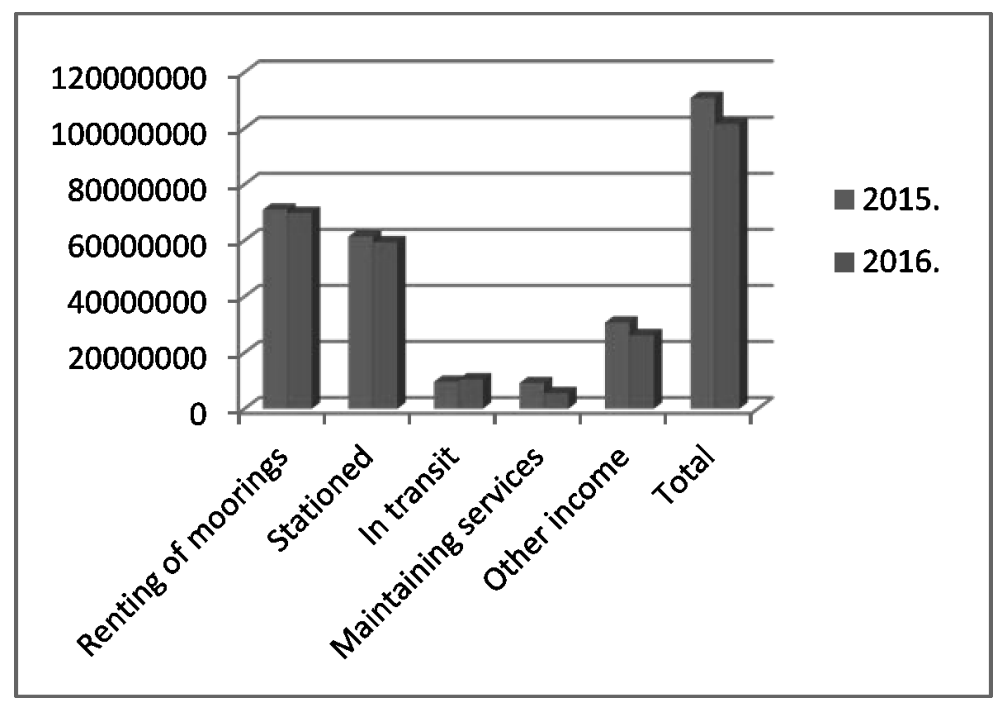

Figure 2 - The analysis of incomes for the County of Primorje-Gorski kotar, according to [11]

It has been noticed that in 2016 the income was approximately by $8 \%$ lower than in 2015. However, despite the evident decline, nautical tourism ports have been taking a more significant place in the overall tourist balance of the County of Primorje-Gorski Kotar. A similar decline was also noted in the County of Istria, while other coastal counties recorded an increase.

The inadequate number of berths represent a problem not only in the County of Primorje-Gorski Kotar, but also in all Croatia. It is particularly worth noting the lack in availability of berths for boats 12 to 15 meters in length and the growing demand 
for berths for yachts more than 20 meters long, as well as the lack in related services/ offers. Despite significant investments in tourist services and facilities, nautical tourism has been stagnating, especially in the County of Primorje-Gorski Kotar.

\subsection{Nautical tourism development projection for the County of Primorje- Gorski Kotar}

By their content, form and occupancy rate, nautical tourism ports may well be the source of prosperity in the coastal area [7]. However, the sensitivity of the coastal area needs to be taken into account in order for the context of the planning process to bring in harmony all ecological, social and economic conditions existing in the planned area. Planning should be developed in accordance with the principles of precaution, sustainability and safety. Particular importance should be given to the compliance with the spatial component as early as in preparatory stages in order for all aspects and possible effects to be considered in time and conflicts to be avoided [5]. The environmental impact assessment study and the analysis of socio-economic impacts are required in order to ensure sustainable management.

With the aim of creating recognizable nautical destinations, the Spatial Plan for the County of Primorje-Gorski Kotar envisages an extension of the existing berthing capacities and construction of new ones long the sea coast, yet with no new dry berthing capacities envisaged on land. An insight in the projects planned by the local self-government units shows that investments in the construction of new berths have been envisaged. The construction of new berths has been planned as follows: 250 in the area of Lovran, 300 in Bakar, 250 in Crikvenica, 400 in Krk, 400 in Stara Baška, 400 in Lopar on Rab, 400 in Martinšćica on Cres and 500 at Peškera in Omišalj. In Nerezine in the area of Mali Lošinj 400 new berths have been planned, and another 300 at Velopin. As for Rijeka, there have been 1300 berths envisaged, out of which 300 at Brajdica (mega yachts and passenger ships) and another 1000 berths at Porto Baroš.

The plans for the County of Primorje-Gorski Kotar were made in the 1990's, but its infrastructure has not progressed since, in contrast to other counties.

Although the Spatial Plan of the County of Primorje-Gorski Kotar has designated new locations for the construction of nautical infrastructure, only two projects have been realized over the 20 years' period and these are in the area of Novi Vinodolski. In 2017, two marinas were opened: one at Muroskva, with the capacity of 180 berths for boats and yachts up to 15 meters in length, and the other in Novi Vinodolski, with the capacity of 204 berths plus 10 dry berths on the shore.

This is still insufficient, however, and it is the responsibility of regional and local administrations to create appropriate, particularly administrative prerequisites to facilitate the process of preparing and obtaining documentation and attracting potential investors. 


\section{Conclusion}

Nautical tourism is considered to be one of the most developed segments of tourism in Croatia and has marked continuous growth in the past decades. However, its developing potential has not reached a full stroke yet.

Capacities of nautical tourism ports in Croatia as a whole, and in the County of Primorje-Gorski Kotar in particular, are inadequate for today's demands, especially during summer months. The demand for berths for accommodation of larger boats and yachts is particularly emphasized. In order to match the world standards of this highly attractive tourism product, the existing infrastructure should be improved and the new one constructed.

The expansion of nautical tourism is an important determinant of the development of the County of Primorje-Gorski Kotar. Given that its spatial potential has all the prerequisites for a more dynamic development of nautical tourism, the construction has been planned of new ports for nautical tourism in order to increase berthing capacities. However, taking in consideration that social and economic requirements should be in compliance with ecological functions.

The construction of new berths and the amplified nautical tourism offer in the County of Primorje-Gorski Kotar would produce direct and indirect benefits. Regional and local governments play a very important role in the development of the County of Primorje-Gorski Kotar as a desirable destination for nautical tourism, since their actions can either facilitate or delay the development process.

\section{References}

1. Čavlek, N., Bartoluci, M., Škorić, S.: Turizam i sport - razvojni aspekti, Školska knjiga, Zagreb, 2007.

2. Gračan, D., Alkier Radnić, R.: Kvantitativna i kvalitativna obilježja nautičkog turizma u strategiji razvitka hrvatskog turizma, Pomorski zbornik 41, 309-318, 2003.

3. Gračan, D., Kovačić, M., Zekić, A. (2015). Can Scuttling Contribute to Expanding the Croatian Tourism Offering, 3rd International Scientific Conference Tourism in Southern and Eastern Europe 2015, 3, 89-101, 2015.

4. Jugović, A., Kovačić, M., Hadžić, A.: Sustainable development model for nautical tourism ports, Tourism and hospitality management, 17(2), 175-186., 2011.

5. Kovačić, M., Luković, T.: Spatial characteristics of planning and construction of nautical tourism ports, Geoadria, 12(2), 131-147, 2007.

6. Luković, T., Bilić, M.: Luke nautičkog turizma u Hrvatskoj i strategija lokalnoga razvoja, Naše more: znanstveno-stručni časopis za more i pomorstvo, 54(3-4), 114-122., 2007.

7. Prostorni plan Primorsko-goranske županije, SN PGŽ, 2013-32, 2013.

8. Strategija razvoja nautičkog turizma Republike Hrvatske za razdoblje 2009.-2019., Ministarstvo mora, prometa i infrastrukture Republike Hrvatske, Ministarstvo turizma republike Hrvatske, 2008.

9. Strategija razvoja turizma Republike Hrvatske do 2020. godine, NN 55/2013,Ministarstvo turizma Republike Hrvatske, 2013.

10. Zelenika, R., Vidučić, V.: Model razvitka nautičkog turizma u Republici Hrvatskoj do godine 2015., Ekonomski pregled, 58(9-10), 522-544, 2007.

11. www.dzs.hr, Izvještaj - Nautički turizam - Kapaciteti i poslovanje luka nautičkog turizma, razna godišta (Accesed 20th November 2017). 
Mirjana Kovačić, Nikolina Eva Pahljina, Astrid Zekić

\section{Komparativna analiza prihvatnih kapaciteta luka nautičkog turizma Hrvatske i Primorsko-goranske županije}

\section{Sažetak}

Hrvatska je jedna od značajnih destinacija nautičkog turizma na Mediteranu, poradi raznih atraktivnih sadržaja, razvedene obale, brojnih otoka, te klimatskih i drugih prednosti. Važan čimbenik u dosizanju punog razvojnog potencijala je razvoj infrastrukture i suprastrukture koji se ogleda kroz ulaganja u izgradnju novih marina, sidrišta te ostale dodatne sadržaje.

U radu se analiziraju prihvatni kapaciteti luka nautičkog turizma Hrvatske. Autori daju pregled sadašnjeg stanja s naglaskom na Primorsko-goransku županiju.

Svrha rada je analizirati rastuću potrebu za prihvatnim kapacitetima u lukama nautičkog turizma. Cilj rada je ukazati na važnost izgradnje novih marina i vezova, posebno za plovila duljine od 12 do 15 metara.

Ključne riječi: nautički turizam, luke, prihvatni kapaciteti, Hrvatska, Primorsko-goranska županija 
